\title{
Molecular characterization of a chromosomal locus in Staphylococcus aureus that contributes to oxidative defence and is highly induced by the cell-wall-active antibiotic oxacillin
}

\author{
Vineet K. Singh, ${ }^{1}$ Jackob Moskovitz, ${ }^{2}$ Brian J. Wilkinson ${ }^{1}$ \\ and Radheshyam K. Jayaswal ${ }^{1}$
}
1 Microbiology Group, Department of Biological Sciences, Illinois State University, Normal, IL 61790, USA
2 Laboratory of Biochemistry, National Heart Lung and Blood Institute, National Institutes of Health, Bethesda, MD 20982, USA

\author{
Author for correspondence: Radheshyam K. Jayaswal. Tel: +1 309438 5128. Fax: +1 3094383722 \\ e-mail:drjay@ilstu.edu
}

Previous studies employing two-dimensional gel electrophoresis and $\mathbf{N}$-terminal protein sequencing have shown elevated synthesis of the enzyme methionine sulfoxide reductase (MsrA) in Staphylococcus aureus in response to cell-wall-active antibiotics. In the present study, the $S$. aureus msrA gene was cloned, overexpressed, purified as His-tagged MsrA and shown to have methionine sulfoxide reductase activity. The transcription of msrA was studied by assaying $\beta$-galactosidase activity in an msrA promoter:: lacz fusion strain and by Northern blot analysis. Transcription of $m s r A$ was increased by oxacillin; but not by a variety of other stresses including $\mathrm{H}_{2} \mathrm{O}_{2}$. Northern blot analysis revealed that the size of the $m s r A$ transcript was $2 \cdot 3 \mathbf{~ k b}$, considerably larger than the $531 \mathrm{nt}$ msrA ORF. The msrA transcription start site was mapped 25 nt upstream of the msrA start codon. Computer analysis from database sequences indicated at least three additional ORFs downstream of msrA. The deduced amino acid sequences of two of these three ORFs showed significant sequence homologies to PilB, and enzyme IIA of the phosphotransferase system, respectively. The third ORF could not be identified by homology searches. Northern blot hybridization with probes specific to the msrA downstream region indicated that the $S$. aureus $m s r A$ was transcribed as part of a polycistronic message. Interestingly, purified $S$. aureus PilB was shown to possess $\sim 28$-fold higher methionine sulfoxide reductase activity than the MsrA. An insertional knockout mutation in the first gene of this operon resulted in increased susceptibility of the mutant to $\mathrm{H}_{2} \mathrm{O}_{2}$ compared to the parent strain, but not to oxacillin.

Keywords: PilB, oxidative stress, MsrA, antibiotic stress

\section{INTRODUCTION}

Methionine residues are readily oxidized to methionine sulfoxide, $\operatorname{Met}(\mathrm{O})$, by several biologically synthesized molecular species such as $\mathrm{H}_{2} \mathrm{O}_{2}$, hydroxyl radicals, hypochlorous acid, chloramines and peroxynitrites (Moskovitz et al., 1997, 1998, 1999). In most instances, oxidation of methionine residues in proteins severely affects their biological functions. Loss of function has been shown to be effectively restored by the reduction of

Abbreviations: $\mathrm{MBC}$, minimal bactericidal concentration; $\operatorname{Met}(0)$, methionine sulfoxide.
$\operatorname{Met}(\mathrm{O})$ back to methionine. Reduction of $\operatorname{Met}(\mathrm{O})$ is mediated by the enzyme peptide methionine sulfoxide reductase, MsrA (Abrams et al., 1981; Moreno \& Pryor, 1992; Vogt, 1995; Wizemann et al., 1996; Moskovitz et al., 1996, 1997, 1998; Sun et al., 1999). Thus, it has been proposed that the methionine residues act as antioxidant defence molecules and prevent oxidative damage to an organism (Levine et al., 1999).

Interestingly, increased expression of MsrA has been observed under different environmental conditions and studies on msrA mutants in various organisms have provided evidence that MsrA functions beyond its role in oxidative stress. In Escherichia coli, MsrA synthesis 
was increased about threefold in stationary phase (Moskovitz et al., 1995), suggesting it to be a stationaryphase response protein. In addition, an increase in $\mathrm{pH}$ of the growth medium has been reported to cause increased $m s r A$ expression in Streptococcus gordonii (Vriesema et al., 2000). MsrA synthesis was also induced in a rabbit model of infective endocarditis (Kili et al., 1999). The MsrA proteins have been shown to contribute to the maintenance of adhesins in three major pathogens, viz., Streptococcus pneumoniae, Neisseria gonorrhoeae and E. coli (Wizemann et al., 1996), and to be a virulence determinant of the plant pathogen Erwinia chrysanthemi (Hassouni et al., 1999).

Although MsrA was determined to have a role in the virulence of Staphylococcus aureus (Mei et al., 1997), its precise role in this bacterium has not been elucidated. We recently identified a $S$. aureus MsrA homologue to be induced in response to cell-wall-active antibiotics (Singh et al., 2001). In this paper, we report on the cloning and molecular characterization of the chromosomal locus that encodes $S$. aureus MsrA. Northern blot analysis indicates that the $S$. aureus $m s r A$ gene is transcribed as a polycistronic message with three additional downstream genes. An insertional msrA knockout mutation increased the sensitivity of the bacterium to oxidative stress conditions.

\section{METHODS}

Bacterial strain, plasmids and growth conditions. The bacterial strains and plasmids used in this study are shown in Table 1. S. aureus and E. coli cells were grown in tryptic soy broth/agar (TSB/TSA; Difco) and Luria-Bertani broth/agar, respectively, at $37^{\circ} \mathrm{C}$ in a shaking incubator (250 r.p.m.) unless stated otherwise. When needed, ampicillin $\left(50 \mu \mathrm{g} \mathrm{ml}^{-1}\right)$, kanamycin $\left(30 \mu \mathrm{g} \mathrm{ml}^{-1}\right.$ in the case of E. coli; $100 \mu \mathrm{g} \mathrm{ml}^{-1}$ in the case of $S$. aureus), erythromycin $\left(20 \mu \mathrm{g} \mathrm{ml}^{-1}\right)$ and chloramphenicol $\left(15 \mu \mathrm{g} \mathrm{ml}^{-1}\right)$ were added to the growth medium.

DNA manipulations. Plasmid DNA was isolated using the Qiaprep kit (Qiagen Inc.); chromosomal DNA was isolated using a DNAzol kit (Molecular Research Center). The Pfu DNA polymerase, restriction enzymes and modification enzymes were purchased from Promega. DNA manipulations, Southern blot and Northern blot analysis were carried out as described by Sambrook et al. (1989). PCR was performed with the GeneAmp PCR system (Perkin-Elmer). Oligonucleotide primers were obtained from Integrated DNA Technology.

RNA analysis. To confirm oxacillin-induced synthesis of MsrA overnight cultures of $S$. aureus were diluted 100 -fold in $25.0 \mathrm{ml}$ of fresh TSB and grown to an $\mathrm{OD}_{600}$ of $0 \cdot 3$. At this point, $1.2 \mu \mathrm{g} \mathrm{ml}^{-1}$ oxacillin (a concentration that was found to be optimum for MsrA induction in our previous study; Singh et al., 2001) was added and the cells were allowed to grow for $1 \mathrm{~h}$. Fifteen millimolar $\mathrm{H}_{2} \mathrm{O}_{2}$ was added to one of the $S$. aureus RN450 cultures to generate conditions comparable to oxacillin stress, as indicated by the degree of growth inhibition. The culture grown for $1 \mathrm{~h}$ without the addition of $\mathrm{H}_{2} \mathrm{O}_{2}$ or oxacillin after reaching a culture density of 0.3 at $\mathrm{OD}_{600}$ was used as a control. Cells were harvested by centrifugation, resuspended in $20 \mathrm{mM}$ Tris/ $\mathrm{HCl}$ buffer $(\mathrm{pH} 7 \cdot 5)$ with $145 \mathrm{mM}$ $\mathrm{NaCl}$, and were lysed by the addition of $50 \mu \mathrm{g}$ lysostaphin for $10 \mathrm{~min}$ at room temperature. Total RNA was subsequently isolated using a Qiagen RNeasy mini kit. Equal amounts of RNA $(10 \mu \mathrm{g})$ from each sample were run on a $1.2 \%$ denaturing agarose gel and transferred to a nylon membrane. The construct pRSETa-msrA was digested with BamHI and HindIII; the $m s r A$ gene fragment was gel-purified, radiolabelled using the Prime-a-Gene labelling system (Promega) in the presence of $\left[\alpha^{32} \mathrm{P}\right] \mathrm{dCTP}$ (specific activity $>3000$ $\mathrm{Ci} \mathrm{mmol}{ }^{-1}[111000 \mathrm{~Bq}]$, ICN Pharmaceuticals) and used to probe the membrane.

Determination of msrA promoter activity under different environmental conditions. Construction of an $m s r A$ promoter: : lac $Z$ reporter strain has been previously described (Singh et al., 2001). In this construct, a $1.3 \mathrm{~kb}$ DNA fragment starting $44 \mathrm{nt}$ downstream and going upstream of the $m s r A$ gene was cloned in the correct orientation in front of the promoterless lacZ gene of the vector pAZ106 (Chan et al., 1998 ) and subsequently fused in the chromosome of $S$. aureus RN450. $\beta$-Galactosidase activity in the reporter strain (control and oxacillin-treated) was assayed using ONPG as the substrate (Miller, 1972).

Primer extension reaction. The primer extension reaction was carried out as described previously (Xiong \& Jayaswal, 1998). Total RNA was isolated from the oxacillin-stressed cells of $S$. aureus and $5 \cdot 0 \mu \mathrm{g}$ of this RNA was reverse-transcribed using primer P1 (5'-CACCAGAAACATCCTCCTGC-3') in the presence of radiolabelled $\operatorname{dATP}\left(\alpha^{32} \mathrm{P}\right.$, specific activity $>3000 \mathrm{Ci} \mathrm{mmol}^{-1}$ ). A DNA sequencing ladder was generated using a 70770 Sequenase DNA sequencing kit (version 2.0 ; USB), primer P1 and an appropriate DNA fragment; the ladder was electrophoresed alongside the product of the primer extension reaction to determine the position of the transcription start site.

Overexpression and purification of S. aureus MsrA and PilB for determination of methionine sulfoxide reductase activity. The $m s r A$ ORF was PCR amplified using $S$. aureus RN450 genomic DNA as the template, a $5^{\prime}$ sense primer (P2) containing a BamHI site (underlined) (5'-GGATCCATGACAAAAGAATATGCAAC- $3^{\prime}$ ) and a $3^{\prime}$ reverse complement primer (P3) containing a HindIII site (underlined) (5'AAGCTTAGCATTTTGATTCCCCCAATGTG-3'). The amplified $m s r A$ gene was cloned in-frame at the BamHI and HindIII sites of the overexpression vector pRSETa (Invitrogen). E. coli strain BLR(DE3)pLysS (Novagen) was subsequently transformed with the construct pRSETa-msrA. The resulting transformants were grown in LB containing ampicillin $\left(50 \mu \mathrm{g} \mathrm{ml}^{-1}\right)$, chloramphenicol $\left(30 \mu \mathrm{g} \mathrm{ml}^{-1}\right)$, and tetracycline $\left(12 \mu \mathrm{g} \mathrm{ml}^{-1}\right)$ to an $\mathrm{OD}_{600}$ of 0.4 and induced for the synthesis of His-tagged MsrA by the addition of $2.5 \mathrm{mM}$ IPTG for $2.5 \mathrm{~h}$. The induced culture was harvested, resuspended in $50 \mathrm{mM}$ Tris/ $\mathrm{HCl}$ buffer $(\mathrm{pH} 7 \cdot 5)$, sonicated, and centrifuged. The supernatant was applied to a nickel-charged-agaroseaffinity-column and eluted with $400 \mathrm{mM}$ imidazole using the Xpress Purification system (Invitrogen). Fractions containing the overexpressed His-tagged MsrA were pooled, dialysed, and concentrated against $50 \mathrm{mM}$ Tris/ $\mathrm{HCl}, 50 \mathrm{mM} \mathrm{NaCl}$, $1 \mathrm{mM}$ DTT, pH 7.5. The methionine sulfoxide reducatse activity of the purified protein was assayed using $1 \mathrm{mM}$ Dabsyl-Met $(\mathrm{O})$ and $20 \mathrm{mM}$ DTT in $50 \mathrm{mM}$ Tris $/ \mathrm{HCl}$ (pH 7.5) following incubation at $37^{\circ} \mathrm{C}$ for $30 \mathrm{~min}$, as described by Moskovitz et al. (1997). The pilB ORF was amplified using $S$. aureus RN450 genomic DNA as the template, a 5' sense primer (P4) containing a BamHI site (underlined) (5'-GGATCCATGCTTAAAAAAGATAAA-3'), and a $3^{\prime}$ reverse complement primer (P5) containing a HindIII site (underlined) (5'-AAGCTTCTTATCAAAATGTGATATTA-3'). The amplified pilB gene was cloned in-frame at BamHI and 
Table 1. Bacterial strains and plasmids used in this study

\begin{tabular}{|c|c|c|}
\hline Strain or plasmid & Characteristics* & Reference \\
\hline \multicolumn{3}{|l|}{ Bacteria } \\
\hline S. aureus RN450 & A laboratory strain of $S$. aureus cured of all the prophages & Novick (1991) \\
\hline S. aureus $\mathrm{RN} 4220$ & A restriction-minus derivative of $S$. aureus $\mathrm{RN} 450$ & Kreiswirth et al. (1983) \\
\hline S. aureus COL & Homogeneous in methicillin-resistance expression & Pfeltz et al. (2000) \\
\hline S. aureus $\mathrm{RN} 450: m s r A$ & S. aureus RN450 with mutation in the $m s r A$ gene $\left(\operatorname{Kan}^{\mathrm{R}}\right)$ & This study \\
\hline S. aureus COL:msrA & S. aureus COL with mutation in the $m s r A$ gene $\left(\operatorname{Kan}^{\mathrm{R}}\right)$ & This study \\
\hline MC1 & S. aureus RN450:msrA with construct pCU1-msr $1\left(\operatorname{Kan}^{\mathrm{R}} \mathrm{Cam}^{\mathrm{R}}\right)$ & This study \\
\hline $\mathrm{MC} 2$ & S. aureus RN450:msrA with construct pCU1-msr $2\left(\operatorname{Kan}^{\mathrm{R}} \mathrm{Cam}^{\mathrm{R}}\right)$ & This study \\
\hline S. aureus PmsrA::lacZ & S. aureus RN450; a reporter strain for the $m s r A$ promoter $\left(\operatorname{Erm}^{\mathrm{R}}\right)$ & Singh et al. (2001) \\
\hline E. coli JM109 & $\begin{array}{l}\text { recA1 supE44 endA1 hsdR17 gyrA96 relA1thi } \Delta\left(\text { lac-proAB) } \mathrm{F}^{\prime}(\text { traD36 }\right. \\
\left.\text { proAB }{ }^{+} \text {lacl }^{\mathrm{q}} \Delta \mathrm{M} 15\right)\end{array}$ & $\begin{array}{l}\text { Yanisch-Perron et al. } \\
\text { (1985) }\end{array}$ \\
\hline E. coli $\mathrm{BLR}(\mathrm{DE} 3) \mathrm{pLysS}$ & An overexpression strain of E. coli $\left(\mathrm{Cam}^{\mathrm{R}} \mathrm{Tet}^{\mathrm{R}}\right)$ & Novagen \\
\hline \multicolumn{3}{|l|}{ Plasmids } \\
\hline pRSETa & An E. coli overexpression vector $\left(\mathrm{Amp}^{\mathrm{R}}\right)$ & Invitrogen \\
\hline pRSETa-msrA & $\begin{array}{l}\text { The } m s r A \text { ORF cloned in-frame in pRSETa at BamHI and HindIII } \\
\text { sites }\left(\mathrm{Amp}^{\mathrm{R}}\right)\end{array}$ & This study \\
\hline pRSETa-pilB & $\begin{array}{l}\text { The pilB ORF cloned in-frame in pRSETa at BamHI and HindIII sites } \\
\left(\mathrm{Amp}^{\mathrm{R}}\right)\end{array}$ & This study \\
\hline pTZ18R & Cloning vector for E. coli $\left(\mathrm{Amp}^{\mathrm{R}}\right)$ & Mead et al. (1986) \\
\hline pCU1 & Shuttle vector $\left(\mathrm{Amp}^{\mathrm{R}}\right.$ in E. coli and $\mathrm{Cam}^{\mathrm{R}}$ in $S$. aureus $)$ & Augustin et al. (1992) \\
\hline $\mathrm{pTZ}-m s r$ & A $2 \cdot 1 \mathrm{~kb}$ DNA fragment encompassing the $m s r A$ gene $\left(\mathrm{Amp}^{\mathrm{R}}\right)$ & This study \\
\hline pTZ-MK & $\begin{array}{l}\text { A kanamycin-resistance cassette inserted in the middle of the construct } \\
\text { pTZ-msr }\left(\mathrm{Amp}^{\mathrm{R}}, \mathrm{Kan}^{\mathrm{R}}\right)\end{array}$ & This study \\
\hline pCU1-msr1 & $\begin{array}{l}\text { The } 1110 \text { bp DNA fragment containing the } m s r A \text { gene under its own } \\
\text { promoter }\end{array}$ & This study \\
\hline pCU1-msr2 & The 2767 bp DNA fragment containing the $m s r A$ operon & This study \\
\hline
\end{tabular}

${ }^{*} \operatorname{Kan}^{\mathrm{R}}$, kanamycin-resistant; Cam ${ }^{\mathrm{R}}$, chloramphenicol-resistant; Erm ${ }^{\mathrm{R}}$, erythromycin-resistant; Tet ${ }^{\mathrm{R}}$, tetracycline-resistant; Amp ${ }^{\mathrm{R}}$, ampicillin-resistant.

HindIII sites of pRSETa, overexpressed, purified, and assayed for methionine sulfoxide reductase activity essentially as described above for MsrA.

Construction of an msrA knockout mutant in S. aureus. To create an $m s r A$ null mutant, primers $\mathrm{P} 1$ and $\mathrm{P} 6{\left(5^{\prime}-\right.}^{\prime}$ AAACCACTACCGAATCGTCG-3') were used to amplify a $1.3 \mathrm{~kb}$ DNA fragment, using $S$. aureus RN450 chromosomal DNA as the template, which represented the left flanking region of the $m s r A$ gene starting $44 \mathrm{nt}$ downstream of the $m s r A$ start codon. Primers P7 (5'-CAGGAGGATGTTTCTGGTGC-3') and P8 (5'-GCCGCCACTTTCTTTAGGTC-3') were used to amplify an $831 \mathrm{bp}$ fragment which represented the right flanking region of the $m s r A$ gene starting $25 \mathrm{nt}$ downstream of the msrA start codon. These two fragments were ligated together in vector pTZ18R (Mead et al., 1986) resulting in the construct pTZ-msr, which simultaneously generated a unique EcoRI restriction site between the ligated fragments. A $1.5 \mathrm{~kb}$ kanamycin gene cassette was inserted into this EcoRI site, resulting in the construct pTZ-MK. The vector pTZ18R cannot replicate in Gram-positive bacteria; thus pTZ-MK was used as a suicidal construct to transform $S$. aureus RN4220 cells by electroporation (Schenk \& Laddaga, 1992). Selection of the transformants on kanamycin plates led to the integration of the entire construct into the chromosome. Phage- $80 \alpha$ was propagated on these transformants and used to resolve the mutation in the $m s r A$ gene in the $S$. aureus strains RN450 and COL by performing transductional outcrosses, as described by Novick et al. (1986).
Determination of the sensitivity of the msrA mutant to oxacillin and $\mathbf{H}_{2} \mathbf{O}_{2}$. The minimum inhibitory concentrations (MICs) and minimum bactericidal concentrations (MBCs) for the $S$. aureus strains were determined as described by Pfeltz et al. (2000) using 96-well microtitre plates with serial dilutions of oxacillin (1000 to $\left.50 \mu \mathrm{g} \mathrm{ml}^{-1}\right)$ and $\mathrm{H}_{2} \mathrm{O}_{2}(12$ to $0 \cdot 125 \mathrm{mM})$ in TSB. The overnight bacterial cultures were diluted to a final concentration of $1 \times 10^{6} \mathrm{cfu} \mathrm{m}^{-1}$ in each well and the plates were incubated at $37^{\circ} \mathrm{C}$ for $48 \mathrm{~h}$. In $\mathrm{H}_{2} \mathrm{O}_{2}$ sensitivity studies, the $m s r A$ mutant was complemented in trans with the msrA gene on the shuttle vector pCU1 (Augustin et al., 1992). To clone the entire $m s r A$ gene into pCU1, a 1110 bp fragment was amplified using the primers P8 and P9 (5'-CAAATCCATTGGTGTCGC-3') starting 254 bp upstream of the $m s r A$ start codon, thus representing the entire $m s r A$ gene. This construct, pCU-msr1, was transferred to $S$. aureus RN4220 by electroporation and subsequently transduced into the $m s r A$ mutant strain resulting in strain MC1. The msrA mutant was also complemented with a $2767 \mathrm{bp}$ PCR-amplified fragment and cloned in the vector pCU1 using primers P9 and P10 (5'CGTCTTTTTCTTCACTACCTC-3'), again starting 254 bp upstream of the $m s r A$ start codon, resulting in strain MC2. To maintain identical conditions during the $\mathrm{H}_{2} \mathrm{O}_{2}$ tolerance study, the wild-type and the $m s r A$ mutant were transformed with the empty plasmid pCU1. Subsequently, the parent and the mutant transformed with pCU1, MC1 and MC2 were diluted to $2.5 \times 10^{7} \mathrm{cfu} \mathrm{m}^{-1}$ from their respective overnight cultures in $100 \mathrm{ml}$ fresh TSB containing $10 \mu \mathrm{g}$ chloramphenicol ml $\mathrm{m}^{-1}$ and 
$8 \mathrm{mM} \mathrm{H} \mathrm{H}_{2} \mathrm{O}_{2}$. The number of c.f.u. in each culture was determined with respect to time.

\section{RESULTS}

\section{Overexpression and purification of MsrA and PilB and determination of the methionine sulfoxide reductase activity}

The $S$. aureus msr $A$ and pilB genes were cloned in the pRSETa vector and overexpressed in E. coli from a T7 promoter by induction with IPTG. The purified proteins appeared to be $>95 \%$ homogeneous on an SDSpolyacrylamide gel. Enzymic activity determination showed that the purified His-tagged MsrA could reduce Dabsyl-Met $(\mathrm{O})$ to $64513 \mathrm{pmol}$ of Dabsyl-Met (mg protein $)^{-1} \mathrm{~min}^{-1}$. Interestingly, purified PilB could reduce the same substrate to $1811929 \mathrm{pmol}$ of Dabsyl-Met (mg protein $)^{-1} \mathrm{~min}^{-1}$, an approximately 28 -fold higher specific activity than the MrrA.

\section{Analysis of $m s r A$ expression}

The expression of the $m s r A$ gene was studied at the transcriptional level to complement the observation of induced MsrA synthesis in oxacillin-stressed S. aureus cells (Singh et al., 2001). In Northern blot analysis, only a faint band corresponding to the $m s r A$ transcript could be detected in the lanes representing RNA from the nonstressed control or $\mathrm{H}_{2} \mathrm{O}_{2}$-treated RN450 cells (Fig. 1, lanes 1 and 2). However, the level of $m s r A$ transcript in the RNA from oxacillin-treated RN450 cells was higher, as a significantly darker band was observed (Fig. 1, lane $3)$. The size of the $m s r A$ transcript on the Northern blot was determined to be $\sim 2.3 \mathrm{~kb}$ (Fig. 1), which is

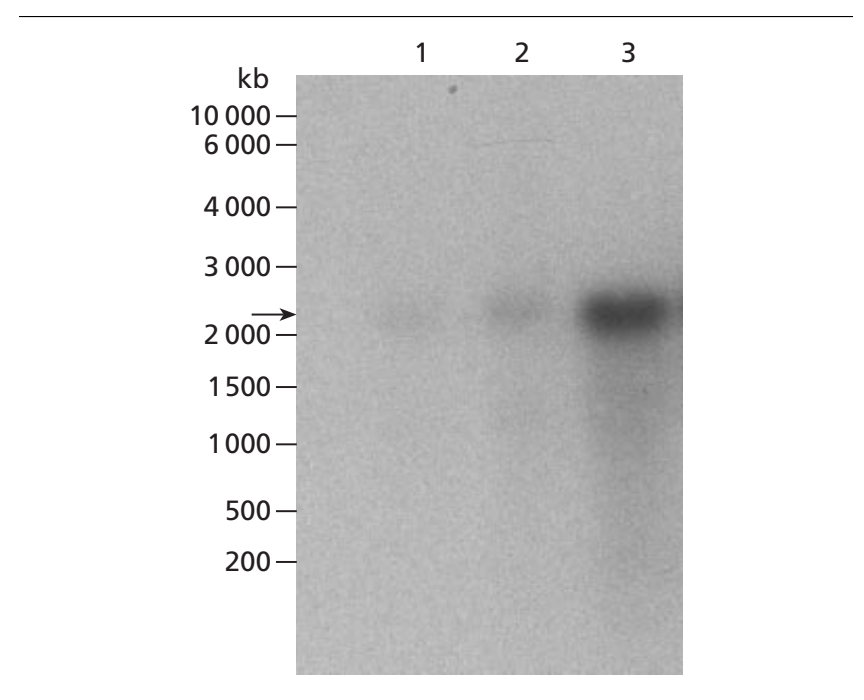

Fig. 1. Northern blot hybridization of the msrA gene with the total RNA isolated from the $S$. aureus cells and separated on a $1.2 \%$ denaturing agarose gel. Lane 1 , total RNA from $S$. aureus RN450 grown in TSB for $1 \mathrm{~h}$ after reaching an $\mathrm{OD}_{600}$ of 0.3 . Lanes 2 and 3, total RNA from $S$. aureus RN450 cells stressed with $15 \mathrm{mM} \mathrm{H}_{2} \mathrm{O}_{2}$ and $1.2 \mu \mathrm{g}$ oxacillin ml $\mathrm{m}^{-1}$, respectively, for $1 \mathrm{~h}$ after reaching an $O_{600}$ of $0 \cdot 3$. The arrow indicates the transcript reacting with the $m s r A$ gene probe.
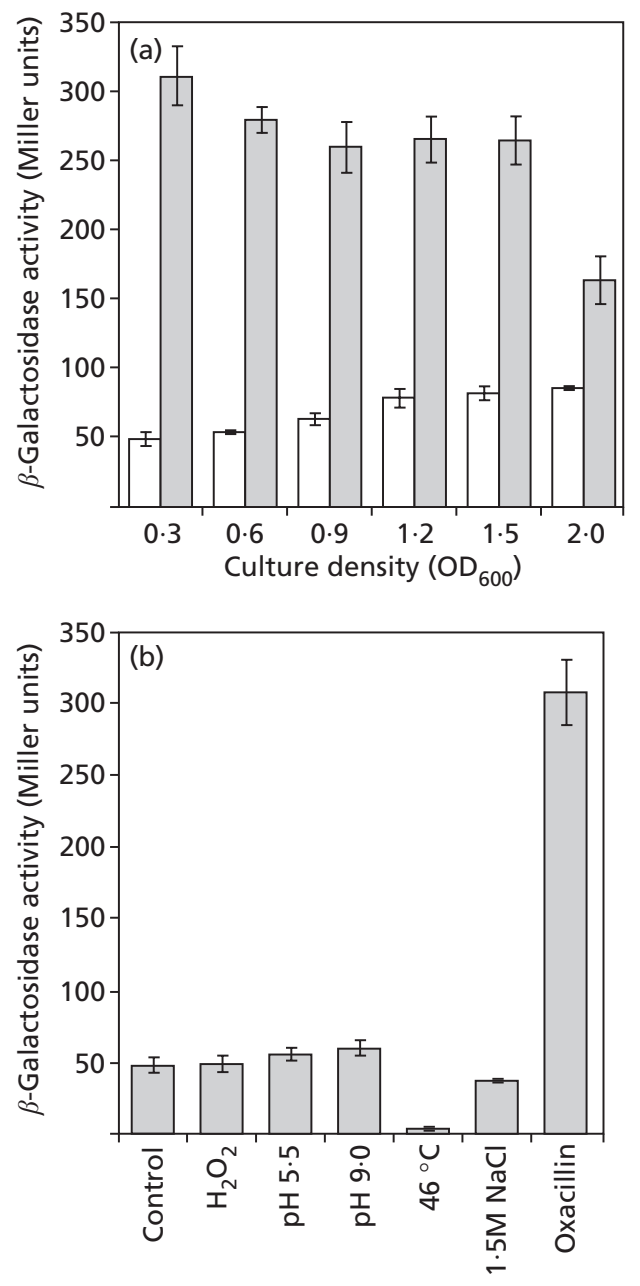

Fig. 2 (a) Expression of $\beta$-galactosidase in the S. aureus RN450 PmsrA::lacZ reporter strain. The growing cultures of the reporter strain were collected at different culture densities and stressed with oxacillin for $1 \mathrm{~h}$. The oxacillin concentrations used were $1.2,2.4,3.6,4.8,6.0$ and $8.0 \mu \mathrm{g} \mathrm{ml}^{-1}$ for cells at culture densities of $0.3,0.6,0.9,1.2,1.5$ and 2.0 at $O D_{600}$, respectively. The control cultures were allowed to grow for $1 \mathrm{~h}$ without oxacillin. The bars represent the mean $\beta$-galactosidase activity (specific activity in terms of $\mathrm{OD}_{600}$ ) of three independent experiments $\pm S E$ : shaded bars represent the values for oxacillininduced cells; open bars represent the values for the noninduced controls cells. (b) Expression of $\beta$-galactosidase in the PmsrA::lacZ reporter strain grown to an $\mathrm{OD}_{600}$ of 0.3 and subsequently exposed to different environmental stresses for $1 \mathrm{~h}$. The bars represent the mean values of three independent experiments $\pm \mathrm{SE}$.

considerably larger than the $531 \mathrm{nt} m s r A$ ORF. Determination of $\beta$-galactosidase activity in an $m s r A$ promoter: :lac $Z$ reporter strain revealed a significant increase in $\beta$-galactosidase activity when actively growing cultures of this reporter strain were exposed to oxacillin (Fig. 2a, b); however, other stress conditions had no appreciable effect when applied for $1 \mathrm{~h}$ (Fig. 2b). These studies also revealed that under normal physiological conditions the msrA promoter is maximally active during late exponential phase (Fig. 2a). In addition, the oxacillin-induced $m s r A$ promoter activity 


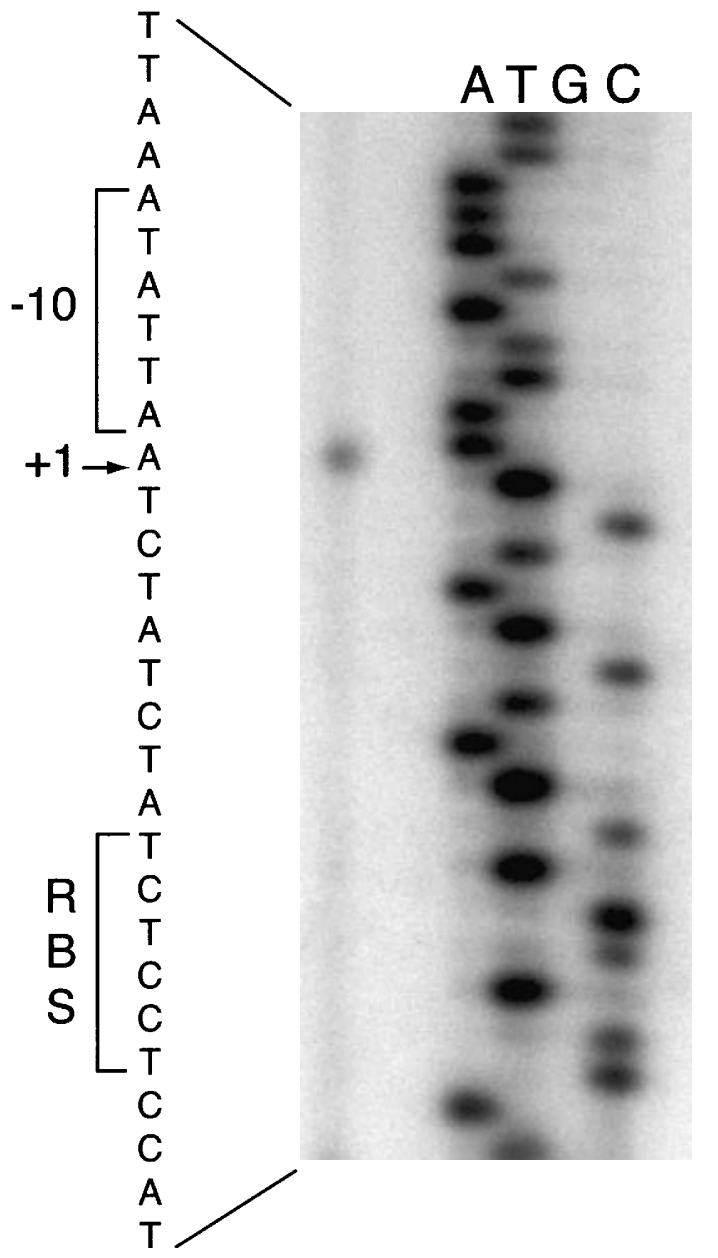

Fig. 3. Mapping of the transcription start site of the msrA gene. The -10 sequences, the transcription start site $(+1)$ and RBS are indicated in the non-coding strand of the $S$. aureus msrA gene.

was apparent in growing cells from early exponential to stationary phase (Fig. 2a). Detection of no apparent $\beta$ galactosidase activity in the reporter strain exposed to $46^{\circ} \mathrm{C}$ might be due to the inactivation of the enzyme at this elevated temperature, rather than to suppression of $m s r A$ promoter activity (Fig. 2b).

\section{Mapping of the $m s r A$ transcription start site and further nucleotide sequence analysis}

The transcription start site of the $m s r A$ transcript was mapped, as we observed a larger than expected $m s r A$ transcript $(\sim 2.3 \mathrm{~kb})$ in Northern blot analysis. The primer extension studies revealed the transcription start site of this $2.3 \mathrm{~kb}$ transcript to be located $25 \mathrm{nt}$ upstream of the msrA start codon. The potential $-10,-35$ sequences $(-35$ sequences not shown in the figure) and ribosome-binding site (RBS) were also identified (Fig. 3). In subsequent computer analysis of the database sequence (http://www.genome.ou.edu/staph.html) and the complete genome sequences of two $S$. aureus strains (Kuroda et al., 2001), the presence of at least three additional ORFs downstream of $m s r A$ has been identified. The deduced amino acid sequences of the first of these three ORFs showed $>50 \%$ homology to the deduced protein product of $y p p Q$ (a pilB family homologue, as per the database entry) of Bacillus subtilis, and to the C-terminus of the MsrA proteins of $S$. gordonii (Vriesema et al., 2000) and S. pneumoniae (Wizemann et al., 1996). The deduced amino acid sequence of the protein product of the second of these three ORFs has been identified as enzyme IIa of the phosphotransferase system (PTS) (Kuroda et al., 2001). The identity of the third ORF could not be established based on homology searches. The RNA blot described above (Fig. 1) was probed again with either the pilB cloned in pRSETa-pilB or a PCR-amplified fragment using primers P11 (5'-CGGAAAAGGCAAAGAAGTTC-3') and P12 (5'-TTGGTCTTGATTGCTTGTTGC-3'). These primers amplified a $968 \mathrm{bp}$ fragment starting $17 \mathrm{nt}$ downstream of the gene encoding PTS enzyme IIa and going further downstream. In these experiments, we observed hybridization of the same band (data not shown) that hybridized with the msrA probe. Additionally, there is no apparent promoter upstream of any of these three ORFs. These findings suggest that the $S$. aureus $m s r A$ gene is transcribed as part of a polycistronic message.

\section{The $S$. aureus msrA mutant showed increased sensitivity to oxidative stress but remained resistant to oxacillin}

Considering that the $S$. aureus MsrA homologue is upregulated in response to oxacillin, an $m s r A$ mutant was created by site-directed mutagenesis in $S$. aureus strain RN450; the mutation was confirmed by Southern blot and PCR analysis (data not shown). However, the oxacillin resistance of the mutant remained unchanged compared to the wild-type parent (Table 2). As RN450 is an oxacillin-sensitive strain, the mutation was transduced into the highly oxacillin-resistant $S$. aureus strain COL. Again, oxacillin resistance in the $S$. aureus $\mathrm{COL}$ $m s r A$ mutant remained unchanged in comparison to wild-type COL (Table 2).

Since MsrA proteins have been shown to contribute to the oxidative stress tolerance of an organism, the sensitivity of the $m s r A$ mutant to $\mathrm{H}_{2} \mathrm{O}_{2}$ was investigated. MIC and MBC determinations revealed that the msr $A$ mutants of strains RN450 or COL were more sensitive to $\mathrm{H}_{2} \mathrm{O}_{2}$ compared to their respective wild-type parents (Table 2). In addition, the $m s r A$ mutant of strain RN450 complemented with the msrA gene alone (MC1) or with the entire msrA operon (MC2) showed higher $\mathrm{H}_{2} \mathrm{O}_{2}$ tolerance than the parent (Table 2). On agar, an identical zone of inhibition around discs soaked with $10 \mu \mathrm{l} 3 \%$ $\mathrm{H}_{2} \mathrm{O}_{2}$ was observed for all four strains; however, $48 \mathrm{~h}$ after incubation a few colonies were apparent in the vicinity of the disc for the parent, MC1 and MC2, but not for the msrA mutant.

Growth kinetics were determined for all four strains in liquid cultures containing $8 \mathrm{mM} \mathrm{H} \mathrm{H}_{2} \mathrm{O}_{2}$. The mutant 
Table 2. Susceptibilities of the $S$. aureus wild-type parents, msrA mutants, MC1, and MC2 to $\mathrm{H}_{2} \mathrm{O}_{2}$ and oxacillin

ND, Not determined; MIC, the lowest oxacillin or $\mathrm{H}_{2} \mathrm{O}_{2}$ concentration that did not allow any bacterial growth; MBC, the lowest oxacillin or $\mathrm{H}_{2} \mathrm{O}_{2}$ concentration that killed the entire population of bacterial inoculum $(>99 \cdot 9 \%)$.

\begin{tabular}{|c|c|c|c|c|}
\hline \multirow[t]{2}{*}{ Strains } & \multicolumn{2}{|c|}{ Oxacillin } & \multicolumn{2}{|c|}{$\mathrm{H}_{2} \mathrm{O}_{2}$} \\
\hline & $\operatorname{MIC}\left(\mu \mathrm{g} \mathrm{ml}^{-1}\right)$ & $\mathrm{MBC}\left(\mu \mathrm{g} \mathrm{ml}^{-1}\right)$ & $\mathrm{MIC}(\mathrm{mM})$ & $\mathrm{MBC}(\mathrm{mM})$ \\
\hline RN450 & $0 \cdot 375$ & $0 \cdot 375$ & $0 \cdot 5$ & $0 \cdot 5$ \\
\hline RN450: $m s r A$ & $0 \cdot 375$ & $0 \cdot 375$ & $0 \cdot 25$ & $0 \cdot 25$ \\
\hline MC1 & ND & ND & $1 \cdot 0$ & $2 \cdot 0$ \\
\hline MC2 & ND & ND & $1 \cdot 0$ & $2 \cdot 0$ \\
\hline $\mathrm{COL}$ & 400 & 400 & $1 \cdot 0$ & $2 \cdot 0$ \\
\hline COL:msrA & 400 & 400 & $0 \cdot 5$ & $1 \cdot 0$ \\
\hline
\end{tabular}

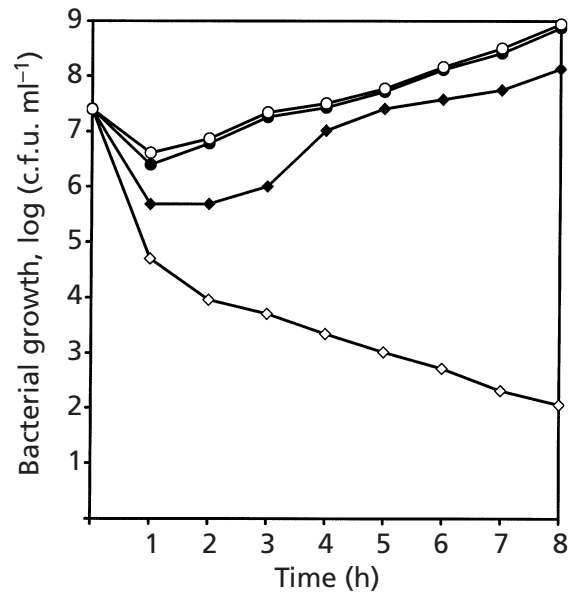

Fig. 4. Growth of $S$. aureus RN450 transformed with pCU1 ( $\bullet$ ), RN450:msrA mutant transformed with pCU1 $(\diamond)$, and RN450: $m s r A$ mutant complemented with pCU1-msr1 (MC1; 0 ) and pCU1-msr2 (MC2; O), in TSB containing $8 \mathrm{mM} \mathrm{H}_{2} \mathrm{O}_{2}$. In each case, the overnight culture was used to dilute $100 \mathrm{ml}$ fresh TSB to $2.5 \times 10^{7}$ c.f.u. $\mathrm{ml}^{-1}$ before the addition of $\mathrm{H}_{2} \mathrm{O}_{2}$ (to a final concentration of $8 \mathrm{mM} ; 0 \mathrm{~h}$ ).

bacteria were almost completely killed under these conditions, whereas the parent bacteria were able to grow after a lag phase (Fig. 4). However, the two complemented clones responded more efficiently and were able to grow more rapidly than the parent (Fig. 4). A similar response was observed in liquid culture of these strains in the presence of $8 \mathrm{mM}$ methyl viologen (paraquat), where the growth of the mutant was slower compared to that of the parent and the two msrAcomplemented strains (data not shown).

\section{DISCUSSION}

Methionine sulfoxide reductases reduce protein-bound or free $\operatorname{Met}(\mathrm{O})$ to methionine and also play an important role in the expression of adhesins (Wizemann et al.,
1996; Moskovitz et al., 1997, 1998, 1999). S. aureus MsrA was recently observed to be upregulated by cellwall-active antibiotics (Singh et al., 2001). In this study, the chromosomal locus that encodes the $S$. aureus MsrA has been characterized at the molecular level.

The active sites of the MsrA enzymes of E. coli and Bos taurus have been mapped and shown to possess an identical active site, GCFWG (Lowther et al., 2000; Moskovitz et al., 2000). Comparative analysis of the amino acid sequences indicates that in the case of $S$. aureus MsrA the characteristic MsrA active site differs at one amino acid: GCFWC in place of GCFWG. However, purified $S$. aureus MsrA was shown to possess methionine sulfoxide reductase activity, which confirms the identity of the oxacillin-induced protein as an authentic MsrA, despite a modified active site. Although the active site of the MsrA in B. subtilis has not been mapped, amino acid analysis indicates that the active site of B. subtilis MsrA (Hayes et al., 1998) is also GCFWC. In this context, very high methionine sulfoxide reductase activity for the protein product of the second gene of the msrA operon is quite interesting as the deduced protein shows $>50 \%$ homology to the family of PilB transcriptional repressors, as per the database entry. However, the precise role of these proteins in the regulation of bacterial transcription is not yet known. More significantly, this PilB homologue was over $50 \%$ homologous to the C-terminus of S. gordonii (Vriesema et al., 2000) and S. pneumoniae (Wizemann et al., 1996) MsrA proteins, as well as those of several other bacterial species. In addition, NCBI database searches indicate that in numerous bacteria the gene encoding this protein is present just downstream of the $m s r A$ gene, in an operon-like organization. This indicates that the presence of a pilB-like gene (along with $m s r A$ ) is conserved across many bacterial species, either as a separate gene entity or as an integral part of a larger $m s r A$. However, to date, none of the PilB proteins that are expressed separately have been reported to possess MsrA-like functions. Interestingly, in the case of $S$. aureus, this 
protein shows 28 -fold higher methionine sulfoxide reductase activity, but it lacks the characteristic active site GCFWG of the MsrA proteins. This indicates that the methionine sulfoxide reductase activity of PilB occurs via different, unknown mechanisms.

We previously observed that cell-wall-active antibiotics induced the $S$. aureus msrA operon (Singh et al., 2001). Studies employing a reporter strain with the $m s r A$ promoter cloned upstream of a promoterless lac Z gene and fused in the chromosome of the $S$. aureus strain RN450 revealed that the $m s r A$ promoter was not inducible by environmental stresses other than oxacillin. Increased expression of $m s r A$ has been reported upon an increase in $\mathrm{pH}$ of the growth medium in $S$. gordonii (Vriesema et al., 2000); however, we did not see any significant increase in the $m s r A$ promoter activity in response to $\mathrm{pH}$ upshift or downshift in this study. Maximum msr $A$ promoter activity in late-exponential and stationary phase is consistent with the observation of a threefold increase in the production of MsrA during this stage of growth in E. coli (Moskovitz et al., 1995). Furthermore, as in E. coli, $\mathrm{H}_{2} \mathrm{O}_{2}$ did not induce the expression of the $S$. aureus $m s r A$ at the transcriptional level. This suggests that $m s r A$ expression is not under the control of the oxyR regulon that controls the oxidative stress response in bacteria (Moskovitz et al., 1995). Although $S$. aureus does not have an OxyR homologue it does have proteins like PerR, which perform similar functions such as regulating the transcription of the gene encoding oxidative stress resistance proteins (Horsburgh et al., 2001).

Interestingly, oxacillin induced the expression of $S$. aureus $m s r A$ but a mutation in the $m s r A$ gene did not affect the oxacillin MIC either in an oxacillin-sensitive or in an oxacillin-resistant staphylococcal strain. However, the msrA mutant showed higher sensitivity to $\mathrm{H}_{2} \mathrm{O}_{2}$ compared to the wild-type parent in the MIC determinations, although there was no appreciable difference in the growth kinetics of the mutant and the parent in liquid culture containing $4 \mathrm{mM} \mathrm{H}_{2} \mathrm{O}_{2}$ or paraquat. The increased sensitivity of the mutant was clearly observed in the presence of $8 \mathrm{mM} \mathrm{H}_{2} \mathrm{O}_{2}$, a concentration considered lethal in most other bacteria. At this concentration $S$. aureus was able to grow after a considerably longer lag; however, the msrA mutant failed to grow at all. For Northern blot experiments $15 \mathrm{mM} \mathrm{H}_{2} \mathrm{O}_{2}$ was added to actively growing cultures $\left(\mathrm{OD}_{600}\right.$ of 0.3$)$ where the bacteria showed higher tolerance, which is believed to be due to increased cell density. In these $\mathrm{H}_{2} \mathrm{O}_{2}$ tolerance studies the msrA mutant, complemented either with the $m s r A$ gene alone or with the entire msrA operon, responded more efficiently than even the wild-type parent. This is probably because of the presence of $m s r A$ on a high copy plasmid. The oxidative stress tolerance of $m s r A$ mutants of E. coli and B. subtilis were comparable to their respective wild-type parents in liquid cultures (Moskovitz et al., 1995; Hayes et al., 1998). In E. coli increased sensitivity to $\mathrm{H}_{2} \mathrm{O}_{2}$ could be seen in $m s r A$ mutants only when grown on agar (Moskovitz et al.,
1995). The authors concluded that the unaffected oxidative stress tolerance of the mutant in liquid culture was probably due to the overriding effects of other protective mechanisms (Hayes et al., 1998). However, the role of MsrA in oxidative stress is visible in liquid culture, which may suggest that MsrA is more important in oxidative stress resistance in $S$. aureus than it is in $E$. coli. In addition, a recent GenBank search reveals the presence of another locus in the $S$. aureus genome that encodes an MsrA-like protein (GI no. 12656489). This protein has also been identified in whole-genome sequence analyses of two methicillin-resistant $S$. aureus strains (GI no. 13701158) (Kuroda et al., 2001). The protein is $50 \%$ homologous to the MsrA reported in the present study and contains the MsrA active site GCFWC; however, the genes encoding these two staphylococcal MsrA proteins share no homology with each other at the nucleotide level. It is also quite likely that this additional MsrA protein accounts for the partial tolerance of our S. aureus msrA mutant to $\mathrm{H}_{2} \mathrm{O}_{2}$, but the bacterium may need both $m s r A$ genes for fullscale recovery under more acute oxidative stress conditions.

A mutant with reduced adherence to type II lung epithelial and human vein endothelial cells was identified in $S$. pneumoniae. The protein encoded by the disrupted gene displayed $>40 \%$ identity with the MsrA of E. coli and $>50 \%$ identity with the C-terminal region of gonococcal PilB (Taha et al., 1988, 1992; Wizemann et al., 1996). In addition, an Erwinia chrysanthemi msrA mutant was less motile on solid medium (Hassouni et al., 1999). A role for MsrA has also been observed in the expression of adhesins in $S$. pneumoniae, N. gonorrhoeae and E. coli (Wizemann et al., 1996). It has been argued that MsrA has a special role in repairing surface layers (Hassouni et al., 1999). However, as MsrA is cytoplasmic and the pilins or adhesins are located outside the cell, the authors speculate that MsrA also functions as a repair system and as a regulator for the production of the extracellular appendices (Wizemann et al., 1996). As MsrA and PilB have been speculated to repair the cell surface (Wizemann et al., 1996), induction of the msrA operon by antibiotics that interfere with cell-wall synthesis might be an attempt by the bacterium to protect its cell surface. However, the roles of MsrA and PilB in the oxidative stress response and cell surface repair need further investigation. Experiments are currently under way to determine the precise roles of the individual ORFs of the msrA locus.

\section{ACKNOWLEDGEMENTS}

We are grateful to Dr Friedrich Götz, University of Tübingen, Germany, for providing the plasmid pCU1 and to Dr Simon J. Foster, University of Sheffield, UK, for the plasmid pAZ106. We thank Dr Anthony J. Otsuka for his critical comments on this manuscript.

This work was supported by a postdoctoral fellowship from the American Heart Association Midwest Affiliate to V.K.S.; 
grant 1 R15 AI43027-01 from the National Institutes of Health to B. J.W; and a grant-in-aid from the American Heart Association Midwest Affiliate to R.K. J.

\section{REFERENCES}

Abrams, W. R., Weinbaum, G., Weissbach, L., Weissbach, H. \& Brot, N. (1981). Enzymatic reduction of oxidized alpha-1proteinase inhibitor restores biological activity. Proc Natl Acad Sci US A 78, 7483-7486.

Augustin, J., Rosenstein, R., Wieland, B., Schneider, U., Schnell, N., Engelke, G., Entian, K. D. \& Götz, F. (1992). Genetic analysis of epidermin biosynthetic genes and epidermin-negative mutants of Staphylococcus epidermidis. Eur J Biochem 204, 1149-1154.

Chan, P. F., Foster, S. J., Ingham, E. \& Clements, M. O. (1998). The Staphylococcus aureus alternative sigma factor $\sigma^{\mathrm{B}}$ controls the environmental stress response but not starvation survival or pathogenicity in a mouse abscess model. J Bacteriol 180, 6082-6089.

Hassouni, M. E., Chambost, J. P., Expert, D., Gijsegem, F. V. \& Barras, F. (1999). The minimal gene set member $m s r A$, encoding peptide methionine sulfoxide reductase, is a virulence determinant of the plant pathogen Erwinia chrysanthemi. Proc Natl Acad Sci US A 96, 887-892.

Hayes, C. S., Illades-Aguiar, B., Casillas-Martinez, L. \& Setlow, P. (1998). In vitro and in vivo oxidation of methionine residues in small, acid-soluble spore proteins from Bacillus species. $J$ Bacteriol 180, 2694-2700.

Horsburgh, M. J., Clements, M. O., Crossley, H., Ingham, E. \& Foster, S. J. (2001). PerR controls oxidative stress resistance and iron storage proteins and is required for virulence in Staphylococcus aureus. Infect Immun 69, 3744-3754.

Kili, A. O., Herzberg, M. C., Meyer, M. W., Zhao, X. \& Tao, L. (1999). Streptococcal reporter gene-fusion vector for identification of in vivo expressed genes. Plasmid 42, 67-72.

Kreiswirth, B. N., Lofdahl, S., Betley, M. J., O'Reilly, M., Schlievert, P. M., Bergdoll, M. S. \& Novick, R. P. (1983). The toxic shock syndrome exotoxin structural gene is not detectably transmitted by a prophage. Nature 305, 709-712.

Kuroda, M., Ohta, T., Uchiyama, I. \& 34 other authors (2001). Whole genome sequencing of methicillin-resistant Staphylococcus aureus. Lancet 357, 1225-1240.

Levine, R. L., Berlett, B. S., Moskovitz, J., Mosoni, L. \& Stadtman, E. R. (1999). Methionine residues may protect proteins from critical oxidative damage. Mech Ageing Dev 107, 323-332.

Lowther, W. T., Brot, N., Weissbach, H. \& Matthews, B. W. (2000). Structure and mechanism of peptide methionine sulfoxide reductase, an 'anti-oxidation' enzyme. Biochemistry 39, 13307-13312.

Mead, D. A., Szczesna-Skorupa, E. \& Kemper, B. (1986). Singlestranded DNA 'blue' T7 promoter plasmids: a versatile tandem promoter system for cloning and protein engineering. Protein Eng 1, 67-74.

Mei, J. M., Nourbakhsh, F., Ford, C. W. \& Holden, D. W. (1997). Identification of Staphylococcus aureus virulence genes in a murine model of bacteraemia using signature-tagged mutagenesis. Mol Microbiol 26, 399-407.

Miller, J. M. (1972). Experiments in Molecular Genetics. Cold Spring Harbor, NY: Cold Spring Harbor Laboratory.

Moreno, J. J. \& Pryor, W. A. (1992). Inactivation of alpha 1proteinase inhibitor by peroxynitrite. Chem Res Toxicol 5, $425-431$.
Moskovitz, J., Rahman, M. A., Strassman, J., Yancey, S. O., Kushner, S. R., Brot, N. \& Weissbach, H. (1995). Escherichia coli peptide methionine sulfoxide reductase gene: regulation of expression and role in protecting against oxidative damage. $J$ Bacteriol 177, 502-507.

Moskovitz, J., Weissbach, H. \& Brot, N. (1996). Cloning and expression of a mammalian gene involved in the reduction of methionine sulfoxide residues in proteins. Proc Natl Acad Sci US A 93, 2095-2099.

Moskovitz, J., Berlett, B. S., Poston, J. M. \& Stadtman, E. R. (1997). The yeast peptide-methionine sulfoxide reductase functions as an antioxidant in vivo. Proc Natl Acad Sci U S A 94, 9585-9589.

Moskovitz, J., Flescher, E., Berlett, B. S., Azare, J., Poston, J. M. \& Stadtman, E. R. (1998). Overexpression of peptide-methionine sulfoxide reductase in Saccharomyces cerevisiae and human $\mathrm{T}$ cells provides them with high resistance to oxidative stress. Proc Natl Acad Sci US A 95, 14071-14075.

Moskovitz, J., Berlett, B. S., Poston, J. M. \& Stadtman, E. R. (1999). Methionine sulfoxide reductase in antioxidant defense. Methods Enzymol 300, 239-244.

Moskovitz, J., Poston, J. M., Berlett, B. S., Nosworthy, N. J., Szczepanowski, R. \& Stadtman, E. R. (2000). Identification and characterization of a putative active site for peptide methionine sulfoxide reductase (MsrA) and its substrate stereospecificity. $J$ Biol Chem 275, 14167-14172.

Novick, R. P. (1991). Genetic systems in staphylococci. Methods Enzymol 202, 587-636.

Novick, R. P., Edelman, I. \& Lofdahl, S. (1986). Small Staphylococcus aureus plasmids are transduced as linear multimers that are formed and resolved by replicative processes. J Mol Biol 192, 209-220.

Pfeltz, R. F., Singh, V. K., Schmidt, J. L., Batten, M. A., Baranyk, C. S., Nadakavukaren, M. J., Jayaswal, R. K. \& Wilkinson, B. J. (2000). Characterization of passage-selected vancomycin-resistant Staphylococcus aureus strains of diverse parental backgrounds. Antimicrob Agents Chemother 44, 294-303.

Sambrook, J., Fritsch, E. F. \& Maniatis, T. (1989). Molecular Cloning: a Laboratory Manual, $2^{\text {nd }}$ edn. Cold Spring Harbor, NY : Cold Spring Harbor Laboratory.

Schenk, S. \& Laddaga, R. A. (1992). Improved methods for electroporation of Staphylococcus aureus. FEMS Microbiol Lett 94, 133-138.

Singh, V. K., Jayaswal, R. K. \& Wilkinson, B. J. (2001). Cell wallactive antibiotic induced proteins of Staphylococcus aureus identified using a proteomic approach. FEMS Microbiol Lett 199, 79-94.

Sun, H., Gao, J., Ferrington, D. A., Biesiada, H., Williams, T. D. \& Squier, T. C. (1999). Repair of oxidized calmodulin by methionine sulfoxide reductase restores ability to activate the plasma membrane Ca-ATPase. Biochemistry 38, 105-112.

Taha, M. K., Larribe, M., Dupuy, B., Giorgini, D. \& Marchal, C. (1992). Role of pilA, an essential regulatory gene of Neisseria gonorrhoeae, in the stress response. J Bacteriol 174, 5978-5981.

Taha, M. K., So, M., Seifert, H. S., Billyard, E. \& Marchal, C. (1988). Pilin expression in Neisseria gonorrhoeae is under both positive and negative transcriptional control. EMBO J 7, 4367-4378.

Vogt, W. (1995). Oxidation of methionyl residues in proteins: tools, targets, and reversal. Free Radic Biol Med 18, 93-105.

Vriesema, A. J., Dankert, J. \& Zaat, S. A. (2000). A shift from oral to blood $\mathrm{pH}$ is a stimulus for adaptive gene expression of Streptococcus gordonii $\mathrm{CH} 1$ and induces protection against 
oxidative stress and enhanced bacterial growth by expression of msrA. Infect Immun 68, 1061-1068.

Wizemann, T. M., Moskovitz, J., Pearce, B. J., Cundell, D., Arvidson, C. G., So, M., Weissbach, H., Brot, N. \& Masure, H. R. (1996). Peptide methionine sulfoxide reductase contributes to the maintenance of adhesins in three major pathogens. Proc Natl Acad Sci US A 93, 7985-7990.

Xiong, A. \& Jayaswal, R. K. (1998). Molecular characterization of a chromosomal determinant conferring resistance to zinc and cobalt ions in Staphylococcus aureus. J Bacteriol 180, 4024-4029.

Yanisch-Perron, C., Vieira, J. \& Messing, J. (1985). Improved M13 phage cloning vectors and host strains: nucleotide sequences of the M13mp18 and pUC19 vectors. Gene 33, 103-119.

Received 18 April 2001; revised 8 July 2001; accepted 31 July 2001. 